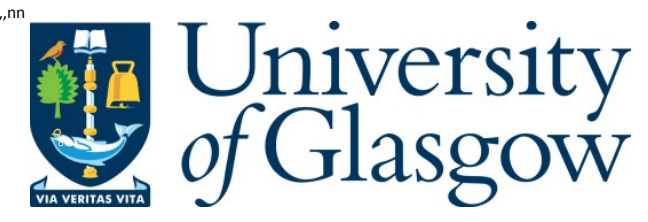

Fox, M . (2013) M anners and method in classical criticism of the early eighteenth century. Cambridge Classical J ournal, 59, pp. 98-124.

Copyright $\odot 2013$ Cambridge University Press

http://eprints.gla.ac.uk/78472/

Deposited on: 11 J une 2015

Enlighten - Research publications by members of the U niversity of Glasgow http://eprints.gla.ac.uk 


\section{MANNERS AND METHOD IN CLASSICAL CRITICISM OF THE EARLY EIGHTEENTH CENTURY}

\section{Matthew Fox ${ }^{\star}$}

University of Glasgow, UK

This article explores a neglected period in the history of classical scholarship: the first decades of the eighteenth century. It focuses on the tension between an evolving idea of method, and the tradition of personal polemic which had been an important part of the culture of scholarship since the Renaissance. There are two case studies: the conflict between Jean Le Clerc and Pieter Burman, and the controversy that followed Richard Bentley's edition of Horace's Odes. Both demonstrate the need to revise current paradigms for writing the history of scholarship, and invite us to reconsider the role of methodology in producing of scholarly authority.

Let Standard-Authors, thus, like trophies borne, Appear more glorious, as more hack'd and torn. And you, my Critics! in the chequer'd shade, Admire new light through holes yourselves have made. Pope, The Dunciad 4. 123-6

\section{Introduction}

In the standard histories of classical scholarship, the early eighteenth century is a period in which rather featureless foundations were laid for the inexorable progress of modern scholarship. ${ }^{\text {I }}$ But the details of those foundations have tended to awaken interest only in

* Email: matthew.fox@glasgow.ac.uk

Material from this chapter was presented to conferences in London and Dartmouth, and to a work-in-progress seminar in Glasgow. I would like to thank the organisers of the conferences: Lorna Hardwick and Chris Stray; Margaret Williamson and Phiroze Vasunia; and the audiences on all occasions. I am grateful to Joy Connolly, Catharine Edwards, Stuart Gillespie, Roger Green, Luke Houghton and Costas Panayotakis, and to the Cambridge Classical Journal's acute anonymous referees and editors.

I Grafton (I99I) 2I6 describes the classical scholarship of the period as terra incognita. Not a great deal has changed in the subsequent two decades, although our understanding of the wider scholarly culture of the period has made 
so far as they correspond to the methods and priorities of later scholarship. Almost without exception, the significant legacies of this period are the isolated moments of brilliance in textual emendation. They provide a few words in the standard texts of many canonical authors, and the names Bentley and Burman are best known today from their occurrence in the small print at the bottom of the page. So the familiarity of the philological project has robbed the era of a distinct character, and there is little to distinguish this work from that produced by the critics of earlier, or later, centuries. ${ }^{2}$ It is the aim of this article to look more closely at the debates that occurred alongside this textual work. Far from resembling earlier periods, the early eighteenth century was characterised by fierce methodological controversies, the ramification within classical scholarship of the advances in thinking about method that were taking place in areas closer to philosophy. The 'battle of the books', most famous today from Jonathan Swift's satire, brought into public view the tension between technical expertise (philological in particular) and broader ambitions for scholarly and intellectual endeavour, setting the terms for a long-running controversy. That debate centres on changing views of the role of classical literature in the wider world of science and culture. ${ }^{3}$ But there is a great deal of writing expressing the same tensions within classical scholarship itself, the vast share of it entirely overlooked in modern discussions. This article aims to rectify that, by looking at discussions of method, and debates about the appropriate literary conduct of the scholar, from the start of the eighteenth century. In its preoccupation with the relationship between the scholar and the community of readers, this material invites reflection on the ethical dimensions of the way in which ancient texts are mediated, and upon the relationship between method and scholarly identity at a crucial era in the evolution of the disciplines. ${ }^{4}$

There are two important aspects of eighteenth-century scholarship that merit preliminary discussion. The first is the continued dominance of Latin as an international language, and the international character of the scholarly community. ${ }^{5}$ Scholars could expect their works to reach across Europe, and although Latin began to be supplanted it naturally remained more prominent in classical scholarship than in other disciplines. The persistence of Latin can also be regarded as a sign of continuity between ancient and modern literature. The

significant advances. Van Miert (2010a) takes a sophisticated view of the constitution of the Republic of Letters in Amsterdam, but his centre of gravity, as of most other studies, lies in the seventeenth century. Mehtonen (20ro) examines the emergence of a recognisably modern idea of literary study later in the eighteenth century, in a volume that is otherwise dominated by studies of the seventeenth. De Smet (I996) is useful on polemic satire, but her end point is 1655 . In being so neglected, classical criticism is something of an exception. As Lane Patey (1997) points out, the period has long been recognised as seminal for its fascination with the idea of the critic, and with the elaboration of theories of criticism.

2 Most (I997) surveys the advances in textual work in this period.

3 Levine (I99I) is fundamental, and draws a close connection between the querelle des Anciens et des Modernes, and the competing claims of gentlemanly education and specialist scholarship.

4 Many of these texts have become more accessible through digitisation. Because they have been so little studied, one of my aims is simply to give an indication of their character.

5 Goldgar (I995) and Bots and Waquet (I997) present a detailed case for the international nature of the scholarly community in this period. See too De Smet (I996) 20-22 on the use of Latin slightly earlier. 
relatively impoverished critical framework for the discussion of literature, which rarely moves beyond the individual word or phrase, and only seldom engages with matters of historical interest, rests upon the assumption that an appreciation of the content of a text requires no effort: once the text has been cleaned up, its communicative value will be clear. The ahistorical quality of much of the criticism of this period and its preoccupation with the production of a readable text are related phenomena. Both suggest that the area of difficulty was not the communicative function of the text, so much as the words and phrases that constitute it. ${ }^{6}$ The persistence of Latin as the dominant language of scholarly communication fostered a certain blindness to historical difference, although scholars did begin in this period to develop the notion of historical criticism. ${ }^{7}$ It is also clear that the lack of a sophisticated critical framework beyond questions of textual editing was not the result of the intellectual shortcomings of individuals (as histories of scholarship sometimes imply), so much as of the fact that most of the basic concepts which contribute to our understanding of critical evaluation (the discreteness of literature from life, the role of the creative artist, notions of taste and appreciation) were born of philosophical and aesthetic discussions that had yet to develop. ${ }^{8}$ Such development, although conventionally attributed to the work of philosophers (Immanuel Kant most prominent among them), was also a response to the growth of national vernacular literatures, and the contrasts that could then be drawn between classical and contemporary texts. The querelle des Anciens et des Modernes was the beginning of a way of evaluating literary texts that ultimately produced what later becomes literary study. Although as early as Montaigne it is possible to find complaints about the futility of textual interpretation, the notion that the meaning of a text needs to be found by delving more deeply into both it, and its cultural context, cannot be taken for granted until much later. ${ }^{9}$ In early eighteenth-century discussions of literary history there is no sense that one of the critic's tasks was to evaluate literary quality, beyond continuing the task of editing and explicating classical texts. Nor is there any idea of a different, linguistically

6 In seeking to bring scholarship forward into the new era dominated by what is usually termed idealism, Friedrich Ast, in the preface to his Grundlinien der Grammatik, Hermeneutik und Kritik (I8o8), makes a plea to move criticism away from its preoccupation with single letters, and make connections between the words on the page and the Geist of antiquity seen as a whole (Ast (I8o8b) pp. iv-vi). In the section on Hermeneutik, he even claims that the individual letter is the expression of this Geist (I8o8b, I9I). Cf. the holistic ambitions announced at the start of his Grundriss der Philologie, Ast (1808a) I-3. Much of the material from the previous century does indeed display a disconnected, text-focused approach. Güthenke (2010) explores the culture in which Ast was working.

7 A pioneering example is the long treatment of Curtius Rufus that closes Le Clerc (I697). Witschi-Bernz (I972b) describes the contemporary debates concerning method in historiography. The accompanying bibliography, Witschi-Bernz (I972a), is useful for theoretical writing of all kinds in this period, in spite of errors and omissions.

8 In Gadamer's history of hermeneutics, it is Schleiermacher, starting work towards the end of the century, who first fully grapples with the idea of a universal possibility of misunderstanding the content of texts. His discussion of Chladenius' I742 dissertation, Einleitung zur richtigen Auslegung vernünftiger Reden und Schriften, adds detail that supports my argument here. Gadamer (2004) I78-84. 'Thus the need for a hermeneutics is given precisely with the decline of self-evident understanding', ibid. I83.

9 See Ormiston and Schrift (I990) I-4, who use Montaigne as a starting point for a consideration of the hermeneutic tradition. 
fragmented, readership for modern literature. The assumption of an unmediated contact with the literature of the Classical period was fostered by the continued use of Latin, not just as a literary language in its own right, but as the standard language for the commentary on and discussion of texts (as indeed, of a wide range of scientific phenomena). ${ }^{\mathrm{IO}}$ Although the critics of this period did recognise to a limited extent that they were dealing with the products of alien cultures, they worked in a tradition of textual commentary that had evolved little since late antiquity, and they perpetuated that discourse in Latin.

The second, and related, context concerns the social organisation of scholarship. This is one area where recent work has made significant inroads into a diverse body of evidence. The groundbreaking study by Goldgar (1995) is informed by social and anthropological theory, and looks at the so-called 'Republic of Letters' in terms of its projected image, and the social and professional relationships between individuals and groups. Goldgar stresses the value placed by members of this community upon the role of polite behaviour in preserving it. ${ }^{\text {II }}$ She defines the republic in terms of the production and reinforcement of a shared set of values, based on the personal interaction between individuals. ${ }^{\mathrm{I2}}$ Others have pursued similar enquiries, focusing on forms of scholarly communication, and upon the aspirations of this republic to a particular kind of identity. ${ }^{\mathrm{I}}$ One of Goldgar's main arguments is of particular relevance to my theme: she sees the evolution of the new learned periodicals of the eighteenth century as aiming to promote the image of scholarship as a civilising and rather gentlemanly realm, an identity that grants the scholar a form of professional identity with wide appeal, making technical expertise seem accessible, and socially acceptable. ${ }^{\mathrm{I}}{ }^{\mathrm{A}} \mathrm{A}$ striking feature of this community was an attachment to inscribing its own genealogy: through writing its own history, in the genre known as historia literaria, and in the publication of the letters and papers of individuals, as well as of compendia. ${ }^{15}$ Two substantial multi-volume directories of scholarship are monuments to this culture: Jöcher's Allgemeines Gelehrten-Lexicon (1750-5I) and its extended

Io It is worth bearing in mind that the phrase philologico-critico (and variations on it) appear regularly in the titles of seventeenth-century scientific treatises, most often where the author combines a scientific study (as we would understand it) with a discussion of references to the phenomenon in ancient texts. The notion of philology as exclusively a textual or humanistic realm depends upon the evolution of ideas of both science and philology along disciplinary boundaries more congruent with modern ones.

II Goldgar (I995) 6-Io. Bots and Waquet (I997) add considerably to the picture Goldgar paints.

I2 In spite of her title, Impolite Learning, Goldgar somewhat neglects the tradition of abusive polemic, concerned rather to air the copious evidence of the mechanisms of social cohesion. But Goldgar (1995) 154-73 and 239-42 are particularly relevant on disruptions to that cohesion.

I3 Several of the essays in Bots and Waquet (I994) give useful detail on the culture of academic communication. See van Rooden (1994) 5I-2 on the role of Latin; Levine (1994) on a variety of fault-lines in the communities of scholarship; van Lieshout (1994) on the role of dictionaries and encyclopaedias in defining the world of scholarship.

I4 Goldgar (I995) ch. 2 (pp. 54-II4). Witschi-Bernz (1972b) 55-7 traces the concept of the anti-pedantic gentleman scholar back to Montaigne's honnête honmme.

I5 Early attempts to provide rules for historia literaria include Richter and Haltermann (I696), Walpurger (I7I5) and, most rigorously, Heumann (I718). Heumann was also a pioneering historian of philosophy, editing the Acta Philosophorum. See Kelley (2002) 4. Wacquet (2000) tackles a landmark example, Morhof's Polyhistor (I689). 
and updated successor, Adelung ( $\left.1784^{-}\right) .{ }^{16}$ These encyclopaedias contain a vast amount of information about a range of often minor scholars, in an era when academic research and publication were only tangentially connected to universities, where the boundaries between disciplines were freer, and where access to publication was easy. A practice begun earlier but continuing well into the eighteenth century was the publication of epistolary exchanges between scholars. ${ }^{17}$ One hundred and twenty of Graevius' letters and prefaces were published in 1707 , for example. ${ }^{18}$ Pieter Burman devoted his retirement to this task. ${ }^{19} \mathrm{He}$ had actually begun his career not with a ground-breaking work of textual editing, but with a similar project, publishing in 1697 a collection of letters between scholars that had been collected by the pioneering epigrapher, Marquard Gude. ${ }^{20}$ There are many other examples of scholars paying tribute to their predecessors, publishing their letters or speeches, and thereby locating themselves in a particular tradition, and of contributing to the sense of the world of scholarship as a coherent group. ${ }^{2 I}$ But the conception of identity of the inhabitants of this republic was different from anything we would recognise today. As Donald Kelley has argued, the articulation of a clear inside/outside (i.e. observer/object) structure for disciplinary self-presentation was a later phenomenon. ${ }^{22}$ These publications were not aimed at producing an objective basis for self-scrutiny, and those producing them were actively inserting themselves into the tradition they were recording. One early attempt to define historia literaria demonstrates the self-regarding nature of this process:

Historia literaria est habitus mentis philologicus, literarum atque artium, earundemque cultorum cum suis ingenii monumentis, convenientem atque accuratam conplectens memoriam, ut sua inde omni literarum atque artium generi, earundemque cultoribus, utilitas atque jucunditas accedat.

Literary history is a philological cast of mind, comprising the accurate and appropriate recording of literature and the arts, and of those who cultivate them, with the monuments of their genius. Its aim is to enhance utility and pleasure for all kinds of art and literature, and their practitioners.

\section{Richter and Haltermann (I696) 3}

I6 Mencke (I7I5a) is a forerunner. Jöcher was Mencke's student: Loh-Kliesch (20I2). In a characteristic manner, Mencke had inherited from his father Otto the editorship of the important periodical, Acta Eruditorum.

I7 Romanus (I698) 33 singles out the epistolary tradition as a defining marker of the commercia litteraria (his phrase) that enhances the Republic of Letters.

I8 The edition included Burman's funeral oration. Graevius (I707).

I9 See Bots and Wacquet (I997) I5I-2, and I72-4. They single out Burman's 1722 Sylloges Epistolarum as the best known example of a pervasive trend.

20 P. Burman (I697) and (I732). Burman's preface to the 1697 collection contains a vivid picture of the so-called Republic of Letters. Maber (2005) reprints a related set of correspondence, with useful commentary.

2I Another revealing example: Burman's son, Caspar, published a directory of the scholars of Utrecht, excluding his own father, but printing a number of celebratory odes in Latin elegiacs, written by a range of supportive eminents, praising his undertaking. C. Burman (I750).

Kelley (2002). 
To define this scholarly genealogy as a habitus mentis, a phrase that recalls Boethius' use of it in defining virtue, is a strong indication of the alien nature of this discourse. ${ }^{23}$ The sense of identity of the scholars of this period is clearly rather different from that which developed later.

Against this background, I now turn to two kinds of writing which express a concern with scholarly ethics, and with manners of scholarly behaviour: publications dedicated to the establishment of methodology, and those motivated by polemic between individuals. Between these two areas, it possible to observe on the one hand the struggle to provide a systematic basis for critical work, particularly on ancient texts, and on the other, the process of competitive self-validation in a climate where claims to methodological stability are themselves new. Methodological discussion is something of a novelty, and I shall discuss one seminal work, the Ars Critica of Jean Le Clerc, published in $1697 .{ }^{24}$ The other kind of writing, polemic, written generally in Latin, and often abusive and personal in its nature, had been a feature of scholarly discourse for some centuries. It begins to die out during this period. However, the contrast between work that strives to provide methodological guidance and give some kind of systematic treatment of the work of the philologist, and the ad hominem attacks that continue to characterise some of that work, are a good indicator of the tensions underlying the main means of achieving a better knowledge of the classical past. ${ }^{25}$ And in that contrast, it is possible to perceive a struggle that is still relevant today: between a socially integrative, anti-specialist view of the function of Classical literature, and a deliberately specialist one, which insists upon the uniqueness of the scholarly intervention, and is given to colourful and sometimes aggressive forms of expression. In the struggle between these two models of scholarly identity, the ideals of the gentleman scholar are under strain, and the battleground is the reception and mediation of ancient texts.

Eighteenth-century readers were aware of this tension. We find scholars complaining about excessive polemic, and less specialist writers promoting a more polite form of literary expression almost as a species of methodological advance. A good example is John Toland's I712 essay on Cicero, Cicero Illustratus, which advertises a (never-realised) complete edition of Cicero designed to improve access to Cicero's great educational and political value. $^{26}$ The edition will have no place for the bad scholarly habits that characterise recent scholarship, including excessive pedantry and polemic, since they

23 Boethius, De topicis differentiis II88C-D: 'Quaestio est de definitione, id est an habitus mentis bene constitutae sit uirtutis definitio.' See e.g. Bejczy (2011) 257-8; Pansters (2012) 27.

24 Le Clerc (1697). The work has received strikingly little attention from classicists. The only recent study is Pitassi (1987), which is more interested in the theological aspects of the work than the philological. Kenney (1974) 40-4 gives a brief discussion. See too J. H. Bentley (I978) esp. 3II-I2.

25 There is further type of writing, related to more conventional historia litteraria: moralising criticism, usually to some degree satirical, on the state of the Republic of Letters. Diverse, and entirely neglected in modern scholarship, classical texts also play a less central role in this material. Examples are Romanus (I698); Lillienthal (I713); Fritze (I720).

26 Reprinted in Toland (I726) vol. I, pp. 23I-96. On Cicero Illustratus see Fox (2007) 274-303 and (2013) 325-9. 
obscure the real value of the Cicero's writings. Toland quotes from a number of commentaries to demonstrate how eminent critics allow excessive pedantry to obscure the reading of the text. ${ }^{27} \mathrm{He}$ also criticises the excessive polemic typical of textual commentary, giving a list of abusive epithets, the kind of language that will not appear in his own work. He compares the rivalries between scholars to those of theatrical troops, and explains their authoritarian manner of expression as a reflection of the absolute imperium over the young men they are educating. ${ }^{28}$ Toland's ambitions were for a more enlightened form of presentation: a Cicero that would serve the educational needs of the élite who were steering Europe towards more rational forms of government and culture. Toland himself was a notorious 'free thinker' and radical. But a similar distrust of scholarly culture can be detected in an author of altogether more orthodox sympathies. Underlying the satire in Swift's The Tale of a Tub (in particular its companion-piece, The Battle of the Books) of I704, there is a serious argument that scholarly practices alienate readers because they lend too great a weight to the voices of the critics, who damage their case further with their rebarbative discourse. ${ }^{29}$ Literature should have higher aspirations. Swift was responding to controversies over the role of criticism which had flared up in the wake of Temple's Essay on Ancient and Modern Learning of I69o, and the related reception of Bentley's dissertation on the epistles of Phalaris. ${ }^{30}$ This controversy had a curious double effect. It made manifest the specialist skills required for expert philological work (in particular, establishing Richard Bentley's reputation as both a scholar and a polemicist). At the same time it consolidated the discourse of non-specialist 'gentlemen scholars', who sought the connections between ancient texts and the wider social and political environment. The subsequent history of these trends is vital to evolution of the humanities during the rest of the century. ${ }^{3 \mathrm{I}}$

27 Toland (I726) esp. 266-72: quam multos locos sanos satis \& castigatos sic jugularunt maleferiati Critici ut ingenii sui acumen, \& ne nihil ex se afferre aut effecisse videantur, ostendant (268). He describes emendation of a sound text as a facinus on 273 .

28 Abuse: Toland (I726) 272-3: neque tantum mihi ipsi unquam permittam, ut quenquam propter opiparas hasce delicias, vel notatas scrupulosius vel neglectas, stipitem appellem, fungum, bardum, asinum, temerarium, impudentem, aut ineptum; ac multo minus ut nequam, mastigiam, scelestum, ferum \& ferreum, sacrilegum, plagiarium, moechum, vel caprarum maritum, talem nominem. Scholarly rivalry: Toland (I726) 275-6. Van Miert (2010b) is a helpful discussion of the rhetoric of such abuse in the work of Joseph Scaliger. Van Miert cites a text which contains several of Toland's epithets: Erasmus' much-read treatise on letter writing, the De conscribendis epistolis (1522).

29 For the place of Swift's texts in both the wider controversies of the period, and those more immediately involving Richard Bentley, see Walsh (2010) pp. Ixxiv-lxxviii. 'Both the Tale and the Battel target and satirize modern philological scholarship; what Swift understood to be a mere pedantry, obsessed with its own learning, of no use or application, barbarous rather than humane, darkening the soul of the text behind its self-generated cobweb of commentary.' Walsh (2010) p. lxxviii. See too Levine (I99I) IIo-20; Hinz (200I) 386-9.

30 See Levine (I99I) I3-I20; Hinz (200I) 313-92. McDayter (2003).

3I An interesting staging-post is Jortin (I73Ia), with its humorous accompaniment, Jortin (I73Ib). At Jortin (I73Ia) 2 we find 'Critics of the highest rank, by not following the rules of humanity, have disgraced their profession', while at (I73Ib) 2 Jortin ironically exaggerates his Miscellaneous Observations as a landmark in historia literaria: it was in English, and cheap: 'This is the first time that ever Criticism was retail'd at Sixpence an Ounce ... where all 


\section{The Ars Critica}

Jean Le Clerc's Ars Critica (1697) does not fit easily into the contrast between bad pedants and enlightened promulgators of the Classics. Indeed, Le Clerc was, as we shall see, a considerable devotee of polemic, although aspiring to combine it with the kind of appeal to a high-minded literary culture that would resonate with Toland's projected readership. In his production of compendia and learned journals, he is emblematic for the newly confident vision of scholarly identity in the Enlightenment, as of a new and broader readership who were subscribing to his journals. His groundbreaking methodological treatise aims at forming the editing of ancient texts into a transparent and systematic activity. ${ }^{32}$ The main purpose of the Ars is to lay down guidelines for the best practice in textual criticism. Le Clerc's apprenticeship had been served in a series of commentaries on biblical texts, and in orientation his work looks as much in the direction of theological and philosophical controversy as towards pagan literature. Questions about dogma, truth and interpretation were more pressing, and far better defined, in the realm of sacred texts; and to its contemporary readers Le Clerc's apparent disregard of the difference between sacred and pagan was challenging. The work does not, however, provide much by way of what we would recognise as hermeneutics, either literary or biblical, even if by itself the idea of tampering with sacred texts would disturb many of his readers. ${ }^{33}$ Nor is it concerned directly with historical research, in the sense of establishing the facts about the classical or Christian past. However, it is striking for the detail of its systematisation of textual criticism, as for its integration of textual-critical skills into a wider educational context. On this basis it aims to account for the processes that allow right judgements to be made when faced with a conflicting manuscript tradition, or a potentially corrupted text.

In its opening sections, the Ars Critica provides a total curriculum in the training of the competent critic. Its first part is devoted to outlining a course of reading that will enable the student to acquire the appropriate knowledge not just of language, but also of particular authors, the subjects that they deal with and worlds in which they lived. Before even beginning to read Latin writers (and thereafter, Greek and Hebrew), Le Clerc prescribes the study of Geography, Chronology and Cognitio Consuetudinum et Opinionum. From there he moves on to discuss a variety of linguistic and stylistic matters, all designed to enable the student to develop an accurate understanding of what actually takes place in an ancient text. The treatise then describes possible sources of textual corruption, and gives a range of examples for the different options for detecting and dealing with it. It also contains sections on distinguishing genuine texts

comers and goers, School-boys, Apprentices, and Chamber-maids are welcome to buy, may all read in their Mother's Tongue a Critique upon Ancient Authors both Latin and Greek'.

His most obvious forerunner was Schoppe ( 1762 ), a thin collection of miscellaneous texts relating to, and demonstrating certain techniques in, textual criticism. Le Clerc's aspirations to theoretical completeness were significantly more developed. 
from forgeries on stylistic grounds. Le Clerc's discussion is dominated by the idea that criticism is a skill that requires the pursuit of a system, and that Le Clerc himself is able to demonstrate both the efficacy of the system (through the inclusion of a large number of examples in Latin, Greek and Hebrew) and the fact that a training in criticism is possible. Some of the distrust concerning habits of scholarship that Toland expresses is visible in the work. ${ }^{34}$ It is also important that Le Clerc has the ambition at least to ground his discussion in a theory of language and of comprehension. ${ }^{35}$ Although there is a long way to go between Le Clerc's use of the term critice and the Kantian Kritik which emerges over half a century later, Le Clerc does show some interest in universal definitions of understanding. But for him understanding, or at least the possibility of misunderstanding, is expressed in linguistic rather than cultural or historical terms. So lack of equivalence between vocabulary in ancient and modern languages receives a certain amount of attention, and there is one chapter devoted to explaining how a high rhetorical style can make comprehension more problematic. ${ }^{36}$ In fact, when dealing with problems of interpretation concerning a particular passage, his terms of reference are more eclectic, but his theoretical insights rather fall short of his practice. In the long essay on Curtius Rufus which concludes the treatise, it is clear that the theoretical apparatus only captures to a degree the full extent of what Le Clerc understands as the activity of criticism. That essay demonstrates, however, that Le Clerc is judging Curtius by universal standards, and has no framework for a more historicist approach. ${ }^{37}$

Most of the immediate controversy that the work produced concerned the application of philological and historical tools to sacred writing, an important caution against the idea of classical textual criticism as a separate discipline. The main reaction to the work was from theologians rather than classicists. In I700, he felt sufficient need to rebut his critics to publish a book of letters, designated as the third volume of the Ars, and in this he rejects criticisms of his handling of theological texts. ${ }^{38}$ None of the sixty or so topics of these letters relate to pagan texts (although some of them do touch on the question of the relationship between Platonic and biblical tradition), and the book ends with a dissertation dealing directly with the question of whether the slanders of theologians

34 E.g. the last of Le Clerc's seven leges emendandi - not in the first, I697, edition, but there in the fourth, of I7I2 - is that textual conjectures should be proposed modestly, so as not to offer an opportunity for mockery. Le Clerc (I7I2) vol. 2, p. 300.

35 Le Clerc (I697) vol. I, pp. I53-62 (i.e. part 2, sect. I, chs. I-2).

36 Le Clerc (I697) 436-70 (part 2, sect. I, ch. I6).

37 E.g. Le Clerc (I697) vol. I, pp. 4I4-I6: modern readers need to be aware that Roman historians are inconsistent in their use of terminology regarding foreign institutions: that is to be regretted. Le Clerc (I7I2) vol. 2, p. 396: all historical writing should aspire to the same standards, irrespective of era or nationality. p. 40I: people should apply the same standards to recent literature as to ancient. Le Clerc's position had become clearer since the first edition, in which these particular passages are absent. On the wider context of the particular controversies regarding historiography, see Witschi-Bernz (I972b). In all of these passages, Le Clerc's aim is to provide a warning against possible sources of error for the critic.

$3^{8}$ Le Clerc (I70o). 
always require a response. Le Clerc's life had been shaped profoundly by controversies over dogma, and he early on chose exile from his native Geneva to avoid the restrictions which his differences from mainstream Calvinism were imposing upon his intellectual ambitions.

In spite of its failure to have much impact in the modern scholarly histories, the Ars struck a chord. By the time Eusebius Amort, a not insignificant Bavarian theologian, published his own much briefer and more philosophical Ars Critica, in 1723, Le Clerc's work had achieved the status of a landmark, and Amort gives a neat summary of its views. ${ }^{39}$ And the Parerga Critica of Christof August Heumann (I712) takes a respectful attitude towards Le Clerc's work, clearly perceiving it as the established authority in this area, even if Heumann is in part motivated by what he sees as defects both in Le Clerc's proposals for critical method, and in some of the emendations he proposes. ${ }^{40}$ Heumann's work also contains, at the close of its preface, a lengthy appeal for the toleration of error, and a quite detailed discussion of the misconceptions and arrogance which motivate some critics: 'imperitum autem maleuolentiaeue suffusum censorum vulgus facile contemno', he exclaims. ${ }^{4 \mathrm{I}}$ Heumann makes a direct plea for a more civilised relationship between scholars. He may well be responding to the recent controversy sparked by Le Clerc's Menander edition, to which I shall soon turn. Heumann also argues for a reasonable degree of disciplinary openness, as well as, more specifically, for a form of textual criticism that looks at larger units of sense than just individual words and phrases.

So there is nothing in the publications that respond to the Ars Critica to suggest that the attempt at a system of criticism was itself regarded as misguided. Nothing, in other words, to prepare us for the later theme in the historiography of scholarship that inspiration, rather than system, is the key to effective criticism, or that the realm of the critic is taste and style rather than method..$^{42}$ What does emerge, however, in other publications from the period, is a debate about the nature of one particular aspect of textual criticism: emendation, and in particular the question of how far, even if the transmitted text is linguistically correct, the

39 Amort (I723). The Ars Critica (very rare but available on Google Books) is the second (and rather shorter) part of a more ambitious three-part work on philosophical and astronomical method. Interestingly, Amort includes a section on the principles of historical criticism: he discusses two further treatises, by Launoyus and R. P. Honoré: the latter a work mentioned briefly by Momigliano (I950) 297 n. 2, in the context of early eighteenth-century works on historical method. As a contemporary review points out, the philosophical context of Amort's critical perspective is important: he emphasises the importance of the probable as a principle in textual criticism. Anon. (1724) 309.

40 Heumann (1712). The Parerga is in fact a collection of short works. The centrepiece is Heumann's own Commentatio de Arte Critica, but there is also an essay containing corrections to some the emendations proposed by Le Clerc in the Ars Critica. The Commentatio was reprinted separately 35 years later. According to Adelung (1784-) vol. 2, col. I977, the editor was a certain Schwarz, probably Christian Gottlieb, 1675-175I, professor of poetry and history at Altdorf. His preface explains that Le Clerc's work was too extensive to be useful in the lecture hall. Heumann (1747) p. v.

4I Heumann (1712) p. xx. As printed, the pages of the preface are unnumbered, the Google ebook has numbers. This comment is on the penultimate page.

42 See Lane Patey (I997) II-22 for a clear statement of the relatively low value placed upon methodology in the period. 
critic is justified, on the basis of his own individual judgement, in improving it by alteration. This theme is central to the debates about the nature of criticism over the ensuing decades, and the manner in which it is discussed intersects closely with the matter of ethics. In particular the attitude towards the manuscript tradition becomes a testing ground for the character of the critic. To anticipate slightly: accusations against bad critics take the form either of personal invective, often involving the charge of linguistic incompetence; or they take the form of castigating that very invective, accusing the adversary of inappropriate personal attack, and of holding up a better kind of scholarly behaviour. The respect for the manuscript tradition, although at first sight unrelated to this dialectic, in fact tends to map onto it. Immoderate polemic is only one aspect of a more pervasive character trait: that of an exaggerated belief in the infallibility of one's own judgement, and a correspondingly excessive intolerance of others' mistakes. In some cases, an exaggerated faith in the critic's expertise is matched with a freedom to depart from the established manuscript tradition.

\section{The battle of Menander}

I now turn to two specific controversies, both of them involving one of the period's most influential critics, Richard Bentley. The first centres on Jean Le Clerc, with Bentley as a minor character; in the second, as editor of Horace's Odes, Bentley takes centre stage. The first was something of a cause célèbre, looked on as shocking even by contemporaries for the intolerance of its polemic, and still talked about decades later. ${ }^{43}$ A partial outline of events was given in a biographical dictionary essay on Le Clerc written many years after his death:

The attack was begun by our learned Bentley, under the name of Phileleutherus Lipsiensis; whose censure, it is said, we know not how truly, vexed Le Clerc to such a degree, that it threw him into a fit of sickness, which lasted several days. Bentley's emendations, as they called it, of Le Clerc's edition, were published at Utrecht in the year I7Io, with a preface written by Burmann; in which there is so much inhumanity and rancour, vented in the most abusive language against Le Clerc, that perhaps the like was never crowded into thirty octavo pages. Burmann had abused Le Clerc, in the preface to his Petronius, published in the year I709; and it was the nature of the man to be foul mouthed, and to abuse every body. Le Clerc did not think proper to make any reply to what Dr Bentley and Burmann had written against him; for, he says, that there is no more necessity for answering always the calumnies of criticks than of divines. The truth is, he plainly saw, that he had given some reason for the exceptions that were made, and therefore thought it better to be silent. However he received a defence of himself from an

43 For a brief narrative, see Golden (I972) 5I-3. 
unknown person, who assumed the name of Philargyrius Cantabrigiensis; and published it in the year I7II, with a preface written by himself. This Philargyrius Cantabrigiensis is said to have been Cornelius de Pauw; a gentleman who has distinguished himself by philosophical and critical publications.

$$
\text { A New and General Biographical Dictionary, vol. } 3 \text { (London } 176 \mathrm{I} \text { ) } 336-7^{44}
$$

As I say, this is only a partial account, and there were further forays into polemic that accompanied these events. ${ }^{45}$ Typically, the British writer overplays Bentley's role. This was in fact just one episode in a long series of conflicts between Le Clerc and Burman, and although it may be true that Bentley's criticism were so unpleasant as to cause Le Clerc pain, he had been the victim of Burman for much longer. ${ }^{46}$ Indeed, Burman's polemic tendency was so well known that no sooner had his edition of Petronius been published than a pamphlet appeared describing his 'calumnies'. ${ }^{47}$ The publications were numerous, with mutual salvoes from Le Clerc and Burman, and allies lining up on both sides. The chronology (and I doubt I have tracked down every episode) is as follows:

1703: Burman publishes a satirical dialogue, Dialogus inter Spidaeum et Gorallum, in which he parodies Le Clerc's critical procedures, making him appear a poorly educated pedant with an enormously over-inflated opinion of himself, as well as cynical and mercenary. Most of the work consists of making the Le Clerc character, Gorallus, describe with great self-satisfaction an absurd process of textual edition and commentary, in which Gorallus makes clear that he has not even the most rudimentary grasp of Latin, and makes excessive and inappropriate use of reference works in order to flesh out his otherwise empty commentaries. ${ }^{48}$

1709: Le Clerc publishes his emendations on Menander. ${ }^{49}$

44 Anon (176I) 336-7. Le Clerc's Menander is Le Clerc (1709); Bentley's pseudonymous pamphlet is [Bentley] I710. Burman becomes Burmannus in Latin, and is usually spelt with ' $\mathrm{nn}$ ' in the eighteenth-century sources.

45 Bentley's hostility to Le Clerc started rather earlier: in the final years of the previous century when he found out that Lord Halifax was planning to install him as a partner to his post as Royal Librarian. Golden (1972) 36-7 gives a brief account. The letter of 1724 , from Joseph Wasse (editor of Sallust and Thucydides) explaining Bentley's behaviour to Le Clerc over twenty years later, is printed in van der Hoeven (I843) 279. See too Levine (I99I) 28I 38 .

46 Part of Burman's hostility seems to be derived from jealousy over the favour of Johann-Georg Graevius, who collaborated with both men, as well as with Bentley. See Maber (2005) II-I2; Golden (1972) 52. In his Petronius preface, it is the protection of the posthumous reputation of Graevius, as well as of Burman's own father, that forms the initial basis for his attack on Le Clerc. P. Burman (1709) top of 5 th page before the end of preface.

47 Anon. (I7ioa).

48 P. Burman (1703). The volume contains no publication details, and is dated to ? 1700 by the British Library and to ? 1705 by the Bodleian. Le Clerc (I710a) 369 makes clear that it was in fact published in 1703. Gorallus was a pseudonym that Le Clerc had adopted in his recent editions of Servius and Albinovanus: Golden (1972) 45 . 
I709: Burman's edition of Petronius appears, including in its preface a lengthy diatribe against Le Clerc. ${ }^{50}$

I7IO: Le Clerc writes a long and scathing review of Burman's Petronius, directed against the obscenity of Petronius, and the consequent lack of moral probity of his editor. However, the majority of the review is taken up with rebutting the accusations made against him by Burman in both the preface and the satire of $1703 . .^{\mathrm{I}}$

I7IO: Bentley publishes his attack on Le Clerc's Menander, with a preface by Burman. ${ }^{52}$ The volume consists of taking passages of the text, pointing out Le Clerc's editorial misjudgements, and suggesting Bentley's own alternatives. In his long and abusive preface, Burman says that he is unaware of Bentley's identity, but compares him to Hercules about to demolish Cacus, praising him as one of the handful of souls in the entire Republic of Letters who rightly understand the process of textual emendation.

I7IO: an anonymous booklet appears criticising Bentley's emendations of Menander. The copy in the British Library contains a pencil annotation indicating that the author was Jacob Gronovius, although on the basis of what evidence, I am unsure. ${ }^{53}$

I7IO: Burman publishes a book of over 200 pages in French attacking Le Clerc, and his periodical, the Bibliothèque Choisie. ${ }^{54}$

I7IO: Le Clerc replies, in an article in the Bibliothèque, explaining why it is beneath him to respond to Burman's attack, and also referring to the satire of $1703 .{ }^{55}$

I7II: a pseudonymous pamphlet attributed to Cornelius de Pauw defends Le Clerc's Menander against Bentley. There is a lengthy preface by Le Clerc. ${ }^{56}$

1734: an anonymous booklet ridicules Burman's Petronius, in terms that recall those of Burman's own satire on Le Clerc. It includes as an appendix a catalogue of examples of Burman's poor use of Latin. ${ }^{57}$

One contemporary commentator took up a perspective that seems an appropriate guide to how we can evaluate the controversy.

50 P. Burman (I709). The pages of the preface are unnumbered, but the attack on Le Clerc occupies most of the last five sides. Burman makes interesting use of the Ars Critica, giving examples where le Clerc's critical incompetence violates his own rules.

$5 \mathrm{I}$ Le Clerc (I7IOa).

52 [Bentley] I7Io.

53 Anon. (I7Iob). Gronovius had a well-recognised reputation for getting involved in polemic exchanges, as the dictionary entry on him in Jöcher ( $\left.175 \mathrm{I}^{-52}\right)$ makes clear. See too Mencke ( $\left.17 \mathrm{I} 5 \mathrm{~b}\right)$ 4I-2. One such exchange was a lively debate with Raphael Fabretti, a scholar from Urbino, over Gronovius' lack of geographical understanding in his emendations of Livy: Gronovius (I684); Fabretti (I686).

54 P. Burman (I7IO).

55 Le Clerc (I7Iob).

56 [De Pauw] (I7II). The review, de la Roche (I7II), does not speculate on the identity of the author. The dictionary entry cited above and Jortin (I790) I22 both identify the author as De Pauw.

57 Anon. (I734). 
I shall conclude this article with these three observations. I. That there is a passage of Philargyrius, in the 5th page, with which M. le Clerc was doubtless very well pleased. 2. That the Commonwealth of Learning has been very peaceful since I began to write these Memoirs. The dispute of M. Burmann and Phileutheros with M. Le Clerc, is, I think, the most noisy Quarrel among the Learned that we have heard of within These Twelve Months. 3. That dispute has not been altogether useless since it has produced Two Volumes of Remarks upon the Fragments of Two Celebrated Poets.

M. D. L. R. (i.e. Michel de la Roche) Memoirs of Literature, 2nd April I7II, $223^{58}$

These words resemble the reflections of Toland on the state of scholarship, but are clearer in articulating the idea that the squabbles between scholars do not, in fact, detract from the value of their work. ${ }^{59}$ Like Toland, the author projects a different kind of audience for scholarship: perhaps their relationship with ancient literature is less professional, but they are nevertheless the readers of these polemic productions. De la Roche takes a wry and rather detached view of this polemic, one that gives little idea of its vividness and tenacity. Again, however, in de la Roche's note, we can detect a vision of a more civilised form of criticism, against which the excesses of the Burman-Le Clerc polemic are seen as defective. $^{60}$

The viciousness of Burman's attempt to destroy Le Clerc's reputation is remarkable. It is not really clear what it is about Le Clerc that drives Burman to such lengths; nor does it become clearer from reading Le Clerc's various defences. It is impossible, however, to reduce it to a simple clash between charlatans and true scholars. Certainly, Burman's subsequent reputation as a textual critic, and the longevity of his work on the text of Petronius, as well as Le Clerc's blinkered moralistic perspective in rejecting Petronius out of hand, make it easier for us to read Le Clerc as a naïve, and over-confident, logorrhoeic, one whose contributions to scholarship are vitiated by a lack of proper linguistic and historical expertise. One of the tropes of Burman's early satire is that financial gain is one of Le Clerc's main motivations, and that he is egged on by equally avaricious publishers into churning out as many commentaries in as little time as possible. Burman is still thought of as a scholar today, whereas Le Clerc has no

58 De la Roche published an expanded version of this review, included in the collected reprint of his articles: De la Roche (I722) vol. 2, pp. 436-9. The passage in question, [De Pauw] (I7II) 4-5 is a vivid repudiation of Bentley's tendency to polarise all critical decisions as either brilliant or completely erroneous, all scholars as either sapientes or stulti, and which ends with the author expressing the fear that Bentley will be poisoned by his own bile. The same journal printed what looks like a review of Bentley's Horace written largely by himself. See Haugen (20II) 150.

59 The point is made explicitly by Mencke, in one of his two declamations de charlataneria eruditorum. Comparing the Republic of Letters to the Roman republic, he argues (without irony, I think) that polemic is an expression of libertas, and that vicious dispute has a role both in enlivening minds and in enhancing study: 'Et dici quidem vix potest, quantum istae eruditorum contentiones tum ad excitandum ingenia, tum ad ornanda litterarum studia valeant' Mencke (1715b) 47. The declamations are themselves good evidence for a more polite audience for scholarly polemic.

6o Lillienthal (1713) $177-8$ also comments briefly on one episode in the controversy. 
reputation to speak of, at least among classicists. On the other hand, Le Clerc was clearly a formidable figure in the theological and philosophical debates of his day, an early encyclopaedist, and friend of, and commentator upon, John Locke. In many respects, he was an intellectual giant of his times, while Burman's field of operation was significantly narrower. But it is hard to rehabilitate Le Clerc on the basis of his high-minded refusal to engage in polemic. As Burman points out in his Gazettier Menteur, Le Clerc's Petronius review is not just damning: it is written with almost the same degree of bile as we find in Burman's writings; indeed, one of Burman's jibes at Le Clerc is that even his polemic comes out of ready-made selections, a jibe that recalls his representation of Le Clerc as heavily dependent, in his commentaries on classical texts, on the work of previous compilers and lexicographers. On the other hand, Burman shows no trace of a consciousness of the shame of engaging in such polemic, something that Le Clerc's more apologetic stance does include, and which seems to have struck contemporary commentators as a clear difference between the two men.

The lining up of scholars on both sides of this conflict would seem to preclude any simple division on the basis of intellectual capability. Burman's assumption that Le Clerc was simply incompetent as a linguist (he accuses him of only being capable of 'un Latin de cuisine') is hardly borne out by the peculiarities of his own understanding of Latin, and the defence of the emendations of Menander. What does emerge on the side of Le Clerc, and, indeed, in the tradition of a more methodical approach to texts, is a greater awareness of the possibility of error. Le Clerc's responses to Burman recognise that he has made mistakes. Heumann's discussions of Le Clerc (referred to above) are clearer evidence for the availability of this trope in the rhetoric of scholarly polemic. Heumann represents himself as a figure who will not claim to be free from error, but who, nevertheless, feels the need to engage with the emendations made by his predecessor in such a manner as to expose them, on occasion, as the product of a hasty or short-sighted critic. Le Clerc's final essay on Burman, entitled 'Raisons pourquoi on ne répond pas au libelle de Mr Pierre Burmann' aims at a similar kind of detached refusal to become embroiled in polemic, as well as containing sections discussing the admission of error. It would be tempting to bring Le Clerc's methodological ambitions to bear on this picture. Perhaps it was they that infuriated Burman, whose first attack occurred not long after the appearance of the Ars Critica, at a point where his own reputation as a critic relied mostly on inserting himself into the scholarly canon by editing the letters of other scholars. Certainly it is possible to take the repeated accusation that Le Clerc relied on a range of cheater's short-cuts for his work as editor as implying that the Ars was itself one of these short-cuts, but the point is not made explicitly. However, much of the satire does rely upon the idea that the status of genuine scholar could only be achieved by a more mysterious process of long study and immersion in the texts, a kind of scholarly connoisseurship that could not be learnt from a book. But Burman and Bentley's main complaint about Le Clerc's Menander is so closely bound in with mistaken decisions over individual lines that there is no clear statement (at least that I've discovered) to the effect that it was the aspiration to a rigorous method that was itself misguided. 


\section{Bentley's Horace and Its Reception}

My final controversy is better known: it concerns Bentley's I7II edition of Horace and its contemporary reception. The controversy is worth revisiting in the light of the conflicts between Burman and Le Clerc, since we can gain a better understanding both of Bentley's views on textual emendation, and of the reaction of his critics, by seeing them within the context of the earlier polemic. ${ }^{6}$ The contrast between a humane aversion to excessive polemic, combined with a desire to treat the ancient text more responsibly, becomes sharper. In the debate sparked by Bentley's Horace, we can detect a clear congruence between Bentley's fondness for polemic, and the attitude with which he approaches the ancient text. The components of the controversy over Le Clerc are clearer to see. It is something of a paradox, of course, that the only figure who acquires in this process the reputation of an innovator is Richard Bentley. Part of my curiosity at these texts is the extent to which modern historians of scholarship skirt over the vociferous objections to Bentley's handling of Horace in the apparent belief that they are motivated not by a consistent attitude to the text grounded in a methodology (which is what their writings suggest), but by a degree of intellectual narrowness that borders on incompetence.

Bentley's Horace, and Richard Bentley generally, have received a great deal more attention than any of the material I have so far discussed. ${ }^{62}$ Bentley himself already had a strong record of polemic publication, having come to prominence in the final years of the previous century with his ground-breaking Dissertation on the Epistles of Phalaris (I697), a work that had polarised the British intellectual community regarding the value of scholarly expertise in the face of polite learning. ${ }^{63}$ In publishing his text of Horace, however, Bentley was more the target of polemic attack than its originator, and although it is possible to see the vigour of his critical decisions as an expression of his abrasive personality, the critical reception, both then and now, centres on the relationship between the critic and the text, and on the evolving idea of method. Most of the modern scholarship on Bentley's Horace limits its scope by taking Bentley's methodology as representative of developing trends in textual practice, and as a sign of progress. ${ }^{64}$ It is not my intention here to re-evaluate Bentley's critical practice per se, but rather, by looking at the texts published in response to Bentley's edition, and considering them alongside the controversies already discussed, to reveal more about the ethical dimensions of the debate, and the associated hermeneutic questions. The central feature of Bentley's Horace is the freedom with which he departs from the current texts, more

6I On Burman's mixed enthusiasm for Bentley's Horace, see Haugen (20II) I5I-2.

62 Haugen's treatment of the reception of the volume is brief, focusing, as most earlier discussions, on textual matters, and passing over most of the material discussed here: Haugen (20II) I49-54. Her exploration of Bentley's intellectual context is, however, very valuable, as is her presentation of the critical challenge presented by Bentley: see esp. I5I and I55. Earlier treatments that give a critical appraisal of Bentley's image and reception are Walsh (1991); Goldgar (1995) I40-42; Gurd (2006).

63 See Levine (I99I) 50-84; Hinz (200I) 344-92. Haugen (20II) IIO-23.

64 See e.g. Walsh (1997); but from a perspective closer to the one adopted here, Timpanaro (2005) 54-7. 
firmly based on manuscript traditions. The negative reaction was swift, but Bentley's reputation has been so enduring that the views of his critics have rarely had adequate representation.

The edition of Horace's Odes was published in two parts, in I709 and I7II. It was recognised at once as a remarkable production: in I7I2, an anonymous tract appeared, listing the places where Bentley had departed from the vulgar tradition, with only a brief preface making clear how important it was for the ordinary reader to realise what enormous liberties Bentley had taken with the text. ${ }^{65}$ The title, Horatius Reformatus leaves little room for doubt that the author's aim is to reverse the deformation of Horace, and the short preface is a hilarious blend of mock admiration for Bentley's critical skills and ironic disdain for the authoritarian nature of his editorial decisions. In few words, the author projects once again a vision of a more responsible form of scholarship, one which the reader will appreciate, and which gives a proper respect to the traditions of the text. The irony of the Greek epithet empsychos applied to Bentley in the dedicatory sentence is particularly revealing: it strikes at the root of Bentley's aspiration to genius, an aspiration which has been validated by three centuries of subsequent Horatian scholarship. For the author of this pamphlet, however, this inspiration was clearly regarded as an inappropriate pose, and the liberty that Bentley has taken with Horace is dismissed as the work of an inspired, but probably deluded librarian. There is nothing to suggest, even in this pamphlet, that its writer did not have a full awareness of what Bentley was attempting; nor that it was a risky undertaking, likely to lead to a worse, rather than better, understanding of Horace.

This pamphlet is far from isolated. In the same year, I7I2, a booklet appeared that takes an altogether less light-hearted approach to the destruction of Horace. Aristarchus Ampullans in curis Horatianis was published under a pseudonym, Philargyrius Cantabrigensis. ${ }^{66}$ 'Ampullans' means, more or less, bombastic, and the subtitle suggests that the author is concerned to preserve Horace from excessive editorial zeal. The work takes the form of a letter to the censor, asking, in a manner that is evidently ironic, that he should take action against the excesses of Bentley's edition: the language is colourful from the outset, and depicts Bentley as a mutilator. The censor must take all measures necessary to heal Horace from his attack. Bentley is just one of a tribe, however, and Philargyrius points to how widespread the voices of complaint are, even quoting Stephanus for a scepticism concerning emendation that parallels his own. ${ }^{67}$ Aristarchus, of course, is the original

65 Anon. (I7I2).

66 [Barnes] I7I2. The pseudonym derives, I believe, from an early commentator on Vergil. Levine (I99I) I6o n.4I points to the uncertainty regarding the authorship of the pseudonymous volume, which is attributed to Bentley's old adversary and Cambridge colleague, Joshua Barnes, in most catalogues - an attribution retained here for reasons of bibliographic consistency. It seems more likely (given Barnes' death in I7I2 and lack of other evidence to connect him with the volume) that this was that same Philargyrius who defended Le Clerc's Menander against Bentley the year before, i.e. J. C. De Pauw. See above, quotation from A New and General Biographical Dictionary, vol. 3 (London $176 \mathrm{r}$ ) and text cued to n. 56 .

67 The same letter of Stephanus provides Jortin (I73Ib) with an epigraph. 
paradigm for such attacks, and is also used by Toland as a byword for excessive critical intervention. Philargyrius homes in on two key words: divinatio and conjectura: and criticises Bentley's repudiation of manuscript tradition in his faith in these tools. He moves on to examine examples, displaying his own erudition and the arbitrary quality, as he sees it, of Bentley's alterations. But his final plea to the censor is unexpected. Bentley's work needs to be re-edited, with a clear demarcation of three types of activity, and these should be marked in the textual apparatus. First, all emendations which are not Bentley's own, with the names either of the editor or of the manuscripts; second, those made on the basis of Bentley's vaunted divine skill at guessing; and third, those where Bentley's skill has let him down, and where the editor feels that the text should not be let stand. Rather wonderfully, the letter ends with its author exhorting the censor with Anchises' words to Aeneas from Aeneid 6:

Tu regere imperio tales, dignissime, cingas:

Hae tibi erunt artes; pacisque imponere morem,

Parcere subjectis \& debellare superbos.

On the expectation, presumably, that Bentley will put up a fight, or retract his text, the censor is either to spare him or to punish.

Richard Johnson, Master of the Free School in Nottingham, provides further useful evidence of the reaction to Bentley. His Aristarchus Anti-Bentleianus appeared in I7I7, and the length and detail of his work suggest that it was the fruit of some years' work. Johnson's preface begins rather unpromisingly as a clunking discussion of the value of criticism. Criticism, he says, has a poor reputation, as being a dry and simple-minded activity, which takes the mind away from a knowledge of affairs into an empty contest of words:

Atque hinc illa in CRITICEN eorum convicia, nempe esse aridum, atque jejunum studium, animum ab rerum cognitione, ad inane verborum certamen abducens.

From here come their slanders against criticism, that it is just a dry and simpleminded pursuit, drawing the mind away from knowledge of affairs towards a empty verbal contest.

Johnson (I7I7) p. i

However, Johnson defends the practice of criticism as a means of understanding ancient literature, with a view to its enhancement of the lives of its readers: the formation of their morals, their rhetorical skill and their understanding of religion from a knowledge of nature. This kind of argument can be found in a similar form in any number of tracts from this period. Toland makes similar but much more detailed claims for the usefulness of Cicero to the education of anyone intent upon a career in public life, as well as for his enlightened attitude towards the superstitious elements of traditional religion. And in any 
number of inaugural and occasional lectures, academics across Europe held forth in this period, as in earlier ones, on the usefulness of a training in classical languages as vital to the production of a civilised society. ${ }^{68}$

Johnson's argument, however, is rather more specific: he does not himself seek, with the publication of a few annotations (annotatiunculae), to be thought of as a critic: that honour is granted to those eminent individuals, too well-known to need naming, who have the kind of learning and judgement that the job demands. Bentley, on the other hand, has spread himself too thinly, along the lines of the proverb of Seneca's, nusquam est, qui ubique est. Johnson can even forgive the pointless heaping up of loci, something which he regards as unnecessary, since such parallels can easily be found by using indices and other means. Let us not forget that this is I7I7! No; Johnson's complaint about Bentley is that, in a difficult field where one has to accept that people will make mistakes, he belongs to that class of critics who embellish their disagreements with each other with personal slander. Beyond that, he states clearly that he regards Bentley as insufficiently experienced in Latin grammar, as lacking the necessary intelligence, judgement and learning. He then explains his case in more detail: Bentley's emendations are marred by basic misunderstandings of the meaning and structure of words, as of the differences of mood and tense. The next hundred and fifty pages go through Bentley's text and dissect his editorial decisions.

Usefully, Johnson finishes his prefatory material with a collection of Bentley's comments, first on his own work, 'Bentlei de se dicta', and then on that of his predecessors, 'Bentlei de aliis dicta'. These are extracted on a line-by-line basis from the commentary, and act as a vivid catalogue of features of Bentley's character, in particular in his relation to the work of his predecessors. In the second category we find ample evidence for the kind of abuse that Toland had described: descriptions of earlier critics having dozed off, ignored the obvious, made ridiculous suggestions. Unfortunately there is no direct corroboration of the more violently abusive epithets listed by Toland. Nevertheless, the pages are a useful proof of the idea that calling scholars names was thought of almost as a separate activity from the work of the scholar itself. With scholarship more broadly in view, Johnson's aim is to demonstrate Bentley's lack of restraint and perspective, and to hold this up in contrast to a more elevated, and respectful vision of the critic's task. At its root is a particular notion of scholarly perspective, one that is shared by several of the texts discussed above. That perspective is based on clarity, respect for the original author, the work of other scholars and a proper sense of the aim of the scholarly undertaking. Interventions of a too individualistic nature are a clear sign of a loss of this perspective.

What was the fate of these serious and lengthy engagements with Bentley's Horace, and the issues that they raise regarding Bentley's love of emendation? I don't think that Brink's History of Classical Scholarship in England can be regarded as a straw target. Its account of

68 Kapp (I722) is a useful collection. The range of orations of the great academicians of the period is further evidence of the boundaries and self-definition of the academy: as well as lectures on the specific disciplines, it includes orations marking events of state, and obituaries. 
Bentley's Horace expresses only admiration, and pays minimal attention to the controversies surrounding the text's publication. 'In sum, then, Bentley's Horace is the foundation document of the new "philology". It may be fairly be said that no edition of any ancient author had ever seen such a complete dispersal of traditional half-sense or non-sense by the power of reason' (with some qualification regarding rashness, inconsistency etc.). 'I am making the point that Bentley's procedure amounts to a fundamentally new and true approach to any text that has come down to us from a remote original by a more or less complex manuscript tradition. ${ }^{69}$

There is much that could be said to expound the nature of the particular 'truth' that Brink ascribes to Bentley's technique. The controversy over Horace was repeated when Bentley re-wrote Paradise Lost using the same conjectural principles twenty years later. ${ }^{70}$ Walsh characterises his approach to Milton as one that privileges the perspective of the individual critic against a sense of historical consciousness. And in a 1993 article re-evaluating some of the Horace conjectures, Konstan and Mueke admire the fact that Bentley treats Horace as a colleague. ${ }^{7 \mathrm{I}}$ We can doubt whether Bentley's contemporaries would have approved either of Bentley's modernity, or of his presumption in taking so familiar an approach to Horace. The boldness that impressed Brink was, to Bentley's contemporaries, the sign of a monstrously misdirected ego, and we have no difficulty in dismissing his Milton along those same lines today. His manipulation of the text was an expression of the same immoderate arrogance as the manner in which he described the work of his colleagues. Both were in clear contradiction to the picture of the humane, community-minded scholar that Goldgar has so copiously analysed. But were a modern philologist to play devil's advocate, the argument would run thus: it is simply because their linguistic capacities were inferior to Bentley's that 'Philargyrius' and Johnson could not perceive the enormous advance represented by Bentley's work. As Nisbet forbiddingly put it in his review of Shackleton Bailey's Bentley-influenced Teubner text, 'Bentley, who is disparaged by the inexpert, now comes into his own'.$^{72}$ In that historiography of philology, Bentley is a giant among pygmies, and the fury his work received, an expression of the blindness frequently elicited by the work of a visionary genius out of step with his times.

Such a narrative, however, pays no regard to the highly developed sense of criticism that obtained at the time. The theme of conjecture was one that had been subjected to theoretical analysis, and it held its place in the prevailing system (it is given detailed treatment in all the treatises discussed earlier), alongside more conservative forms of emendation. Generally

69 Brink (1986) 7I. Glenn Most gives a succinct account of the generic limitation of work such as Brink's in his introduction to Timpanaro (2005) 15. For Timpanaro's own scepticism regarding Brink's on Bentley, see Timpanaro (2005) $56 \mathrm{n} .37$.

70 See Walsh (I99I) and (1997); Levine (1991) 245-63.

7 I Konstan and Mueke (1992-93). Similarly, Levine, whilst placing Bentley diligently within his context, has no qualms about comparing him, in terms of intellectual progress, to Newton: Levine (I99I) 64 .

72 R. G. M. Nisbet (1986) 229. Noteworthy too is Renehan's sense that the dominance of Bentley in the Shackleton Bailey's Teubner text of Horace is what marks it out as of particular use to the scholar: Renehan (I988) 327-8. 
speaking, conjecture was more closely linked to the manuscripts than the manner in which Bentley employed it. ${ }^{73}$ A treatise on criticism from later in the century is a useful reminder that the choices available to eighteenth-century readers were rather more sophisticated than history of scholarship has generally allowed:

There were numerous Corruptions in many of the finest authors, which neither ancient Editions, nor Manuscripts could heal. What then was to be done? - Were Forms so fair to remain disfigured, and be seen for ever under such apparent blemishes? - 'No' (says a Critic), 'Conjecture can cure all - Conjecture, whose performances are for the most part more certain than any thing, that we can exhibit from the authority of Manuscripts,' - We will not ask, upon this wonderful assertion, how, if so certain, can it be called Conjecture? 'Tis enough to observe (be it called as it may) that this spirit of Conjecture has too often past into an intemperate excess; and then, whatever it may have boasted, has done more mischief by far than good. Authors have been taken in hand, like anatomical subjects, only to display the skill and abilities of the Artist;

Harris (I78I) 34-35

These sentiments may be applied even to the celebrated Bentley..... the rage of Conjecture seems to have seized him, as that of Jealousy did Medea; a rage which she confest herself unable to resist, altho' she knew the mischiefs, it would prompt her to perpetrate.

Harris (I78I) 37

\section{Synthesis}

The material discussed here demonstrates the struggle between scholars for authority over the work of the critic, and the difficulty of defining that work. For Le Clerc, and those influenced by him, criticism is beginning to look like a method, capable of definition. For others, such as Richard Johnson, the critic is characterised by the degree of erudition, rather than method, and an appropriate attitude to the text. The nature of the critical intervention is complex: in Bentley's hands, we can clearly observe a blurring of the boundaries between text, critic and scholarly tradition. But such a blurring is also discernible in the tradition of historia literaria, as well as in the critical standpoint elaborated by Le Clerc. In Bentley's work it looks extreme, but that is largely just the expression of his eccentric character. And whilst Bentley's actual writings foil any attempt to systematise the principles underlying his critical practice, his over-reliance on conjecture nevertheless operates within a repertoire of tools that were widely accepted. ${ }^{74}$

73 The history of this emendatio ope codicum is describes in Timpanaro (2005) 45-57.

74 Le Clerc's response to Bentley's Horace bears witness to the idea that it was the balance, not the approach itself, which was at fault. See Haugen (20II) I46-7. 
It is unlikely that Bentley's critics had a more refined sense of historicism. It was just that they were less insistent on relying on one particular technique.

The production of a new version of Horace or Milton makes the critic the focus for renewal, and after his treatment those authors will speak in the critic's voice; as Harris puts it, critics had become like artists, reworking their authors. The modern reception of Bentley makes clear what the stakes are in either accepting or repudiating that approach, while Bentley's first readers were more anxious and vocal concerning the pitfalls. The dispute between Burman and Le Clerc, like the controversy over Horace, demonstrates the degree of excitement that could be produced by the suspicion of the critic aspiring to an inappropriate form of power, or exhibiting a lack of respect to his peers. At the root of both of these controversies, there lies a heritage of scepticism, which the Enlightenment project was itself helping to supplant. The brazen confidence of Bentley was an assault upon the conceptual model of the reader as an active participant in the process of interpretation: his texts supplanted, rather than improved upon, the vulgar tradition. As Timpanaro puts it, Bentley corrected not the manuscript tradition, but Horace himself. ${ }^{75}$ It was the sceptical model which generated the variorum editions of texts, or ones like Le Clerc's Menander, which were more selective in using the opportunity of an edition not just to promote the new interpretations of the critic, but also to bring to bear the insights of predecessors whose annotations may not before have reached publication. In this model, the judgement of the reader is respected, just as, for example, in his Dictionnaire Critique Pierre Bayle would often include several accounts of the same subject by different authors. Bentley's attackers were weighing in to safeguard the rights of readers, and their response was to ensure that the traditional text be preserved alongside Bentley's changes. Bentley was disempowering them, ignoring his own fallibility, and misjudging the expertise of those who were reading his edition.

It is clear that Bentley and Burman, with their unrestrained polemics, were working in the face of a coherent sense of the virtuous attitude to the ancient text and to their colleagues, as can be seen from a range of comments that suggest that their reactions were extreme, and that they were obstructing the polite reader's access to advances in scholarship. De Le Roche's evaluation, that the battle for Menander had at least yielded results for the responsible reader, is instructive. It suggests that polemic and scholarship were accepted as aspects of the same project; and it is worth at this point recalling the vigour with which the lives and writings of scholars were recorded: celebrity and personality were an intrinsic part of the critical world-view. The polemical tracts on textual problems that proliferate in this period show that it was Bentley's unrestrained enthusiasm for conjecture that was the problem, rather than his desire for a better, more readable text: that was a universal aim. The texture of those polemic-laden tracts in which scholars weighed up in minute detail the arguments of centuries of scholarship and manuscript variants, makes them almost unreadable today. But they clearly had some 
importance for a wider readership who would not aim to match the textual expertise, but who would still feel that they could benefit from the result of the pedants' labours. These same readers can be envisaged as potential users of Le Clerc's Ars Critica. The promise of method is, in part, to demystify criticism, and to make it accessible to anyone prepared to undergo the necessary educational regime. But method did not itself legislate for the forms of scholarly expression, nor define the boundaries of the community. Irrespective of his methods, the virtuous critic would not allow his own personal preoccupations to obscure the reading of the text, nor would he engage in excessive polemic. He would be aware of the possibility of his own error and exercise a tolerant respect of the shortcomings of other readings.

Both methodological transparency, and a respect for the community of scholars, were working to contain the work of the critic, guarding readers from unpleasant surprises of several types: an unwarranted departure from the manuscript tradition, an eruption of scholarly ill-temper, or, in the case of Petronius and others, a form of obscenity from which they had been protected by the discretion of earlier editors. ${ }^{76}$ It is possible to see in this range of attitudes towards the function of scholarship, and the forms of scholarly expression, a more lurid version of the forms of communication current in the disciplines today. The arguments of Bentley's first readers, and the elision of their complaints in the current canon, demonstrate vividly the shifts in fashion in textual criticism. The (perhaps equivocal) reputation of textual criticism today rests, I think, upon a misconception that it has a greater methodological fixity than those areas of literary or historical interpretation where the imagination is more clearly at work. That misconception is in part a response to the fact that, whilst still central to the disciplines, relatively few individuals now regard themselves as traditional philologists. These early debates about textual criticism suggest, however, that method is not in itself the central issue. Bentley's critics were not reacting to Bentley's choice of method as such, but to the excessive liberty with which he granted to his own imaginative inventions. ${ }^{77}$ In a paradoxical manner, debates over method were aiming both to put philology onto a sound footing by outlining principles, but at the same time, seeking to eliminate excessive individuality, and to tie the text to a process of evolution by slow alteration of tradition, rather than by great leaps.

In this tension between gestures of great individuality, and the maintenance of a polite consensus, a pattern is set for our own disciplinary situation. Of greater significance, however, is the fact that, in comparison with a modern scholarly discourse in which the critic's individuality has been largely occluded, the conversations of this earlier period rest on a link between the values of the individual as a member of the community, and

76 An interesting parallel is the first separate edition of the twelfth book of the Greek Anthology, dating to 1764 . The editor, Christian Adolf Klotz, something of a pioneer in the development of a more literary approach to ancient texts, makes an apology for the homoerotic content of his work, and needs to defend its publication by arguing that as love poetry it is scarcely different from that of the Roman elegists. That said, he leaves out all the more sexually explicit items. Klotz ( 1764$)$.

77 See Haugen (20II) I53-55. 
the labour of interpreting ancient texts. Readers then were more interested in the personality of the critic. The self-presentation of Bentley, Burman and Le Clerc, and their willingness to delineate their own characters as responses to attacks from their colleagues, as well as in relation to their critical forerunners, all suggest that the character of the critic was an aspect of the persuasive appeal of their expertise. In that respect, perhaps, recent trends in personalising the critical voice are effecting something of a loosening of the restraint that has occurred in the centuries that separate us from these forebears. That restraint in turn can be read as a response to the blossoming of an idealised, almost erotic version of the encounter with antiquity, which the work of Winckelmann, Herder and others gave rise to at the end of the eighteenth century. ${ }^{78}$ Ultimately, the Romantic engagement with antiquity led to a bifurcation between mavericks working in the idealistic tradition (Nietzsche, Bachofen, Toynbee) and those who channelled monomania effectively into an academic discourse (Mommsen, Wilamowitz). Before classical philology became so effectively disciplinised, the proper representation of the text was the focus of strong passions, and character and individuality were shaped by it, even if only by standing back in horror at the excesses of the professionals. In its appeal to the wider public of benign readers, the discourse surrounding the early eighteenth-century critics tends towards a consensus. At the root of that is still, in spite of potential mishandling, a desire to get classical texts to work more effectively. It is an intriguing paradox in this tradition that today the expertise of Richard Bentley is the best-known survivor from these controversies, but one that says something about our own troubled relationship with the formation of our disciplines.

\section{Works cited}

Adelung, J. C. (1784-) Fortsetzung und Ergänzungen zu Christian Gottlieb Jöchers allgemeinen Gelehrten-Lexicon, Leipzig.

Amort, E. (1723) Nova philosophiae planetarum et artis criticae systemata, Nuremberg.

Anon. (I7Ioa) Burmanniana sive calumniarum Petri Burmanni in collegas et populares specimen, Amsterdam.

(I7Iob) Infamia emendationum in Menandri reliquias nuper editarum trajecti ad Rhenum auctore Phileleuthero Lipsiensi, Leiden.

(I7II) Philargyrii Cantabrigiensis emendationes in Menandri et Philemonis reliquias, Amsterdam.

(I7I2) Horatius reformatus: sive emendationes omnes quibus editio Bentleiana a vulgaribus distinguitur summa fide in unum collectae, London.

(1724) review of Amort (1723) in Acta Eruditorum anno MCCXXIV, Leipzig, 306-Io.

(1734) Chrestomathia Petronio-Burmanniana, Florence.

(176r) 'Le Clerc, John', in A New and General Biographical Dictionary, vol. 3, London, 323-39.

Ast, F. (1808a) Grundriss der Philologie, Landshut.

(I8o8b) Grundlinien der Grammatik, Hermeneutik und Kritik, Landshut.

[Barnes, J.] Philargyrius Cantab. Aristarchus ampullans in curis Horatianis; sive querimonia epistolaris de impestiva ista corrigendi libidine, tum de ea opportune cohibenda, ne indies pessime inquinati prodeant optimi auctores, London.

78 See Güthenke (20I0) with bibliography. 
Bejczy, I. P. (20II) The cardinal virtues in the Middle Ages, Leiden.

Bentley, J. H. (1978) 'Erasmus, Jean Le Clerc, and the principle of the harder reading', Renaissance Quarterly 3I, 309-32I.

[Bentley, R.] Phileleutheros Lipsiensis (I7Io) Emendationes in Menandri et Philemonis reliquias, Utrecht.

Bots, H. and Waquet, F. (eds.) (I994) Commercium litterarium, Amsterdam.

Bots, H. and F. Waquet (1997) La République des lettres, Brussels and Paris.

Brink, C. O. (I986) English classical scholarship, Cambridge.

Burman, C. (1750) Traiectum eruditum, Utrecht.

Burman, P. (I697) Marquardi Gudii et doctorum virorum ad eum epistolae. Quibus accedunt ex Bibliotheca Gudiana clarissimorum et doctissimorum virorum, qui superiore et nostro saeculo floruerunt; et Claudii Sarravii epistolae ... curante Petro Burmanno, Utrecht.

(I703) Dialogus I inter Spidaeum et Gorallum, n.d., n.pl.

(I709) Titi Petronii Arbitri Satyricon quae supersunt, Utrecht.

(I7I0) Le Gazettier menteur, Utrecht.

(1723-) Thesaurus antiquitatum et historiarum Italiae, 9 vols, Leiden.

(I732) Petri Cunaei et doctorum virorum ad eumdem epistolae, Leiden.

De La Roche, M. (I7II) Review of [De Pauw] (I7II) in Memoirs of literature, Monday, 2 April I7II; reprinted I712, vol. I, p. 223, London.

(I722) Review of [De Pauw] (I7II) in Memoirs of literature, vol. 2, pp. 436-9, London.

[De Pauw, C.] (I7II) Philargyrii Cantabrigensis emendationes in Menandri et Philemonis reliquias, Amsterdam.

De Smet, I. A. R. (1996) Menippean satire and the Republic of Letters: 1581-1655, Geneva.

Fabretti, R. (I686) Ad Jacobum Gronovium apologema in eisuque titiliuitia sive somnia de Tito Livio animadversiones, Naples.

Fox, M. A. (2007) Cicero's philosophy of history, Oxford.

(2013) 'Cicero during the Enlightenment', in C. Steel (ed.) The Cambridge companion to Cicero, Cambridge, $318-36$.

Fritze, L. A. (1720) De eruditione noxia dissertatio philosophica et historica, Leipzig.

Gadamer, H.-G. (2004) Truth and method, 2nd rev. edn, London.

Golden, S. A. (1972) Jean Le Clerc, New York.

Goldgar, A. (1995) Impolite learning: conduct and community in the Republic of Letters, New Haven, CT, and London.

Graevius, J. G. (1707) Praefationes \& epistolae CXX in usum latinae eloquentiae studiosorum collectae et editae a Jo. Alberto Fabricio, Hamburg.

Grafton, A. (I99I) Defenders of the text, Cambridge, MA, and London.

Gronovius, J. (I684) Responsio ad Cavillationes R. Fabretti, Leiden.

Gurd, S. A. (2006) 'Richard Bentley's radical philology', Classical and Modern Literature 26, I-2I.

Güthenke, C. (2010) 'The potter's daughter's sons: German classical scholarship and the language of love circa I80o', Representations I09, I22-47.

Harris, J. (178I) Philological inquiries in three parts, London.

Haugen, K. L. (20II) Richard Bentley: poetry and Enlightenment, London.

Heumann, C. A. (I712) Parerga critica sive hedbomadum criticarum hebdomas et glossematum decas, Jena.

(I7I8) Conspectus reipublicx literarix, sive via ad historiam literariam juventuti studiosx aperta, Hanover.

(1747) Commentario de arte critica, Nuremberg and Altdorf.

Hinz, V. (200I) Nunc Phalaris doctum protulit ecce caput: antike Phalarislegende und Nachleben der Phalarisbriefe, Munich.

Jöcher, C. G. (1750-5I) Allgemeines Gelehrten-Lexicon, Leipzig.

Johnson, R. (I7I7) Aristarchus anti-Bentleianus: quadraginta sex Bentleii errores super Q. Horatii Flacii odarum libro primo spissos nonnullos et erubescendo: item per notas universas in Latinitate lapsus foedissimos nonagintae ostendans, Nottingham.

Jortin, J. (I73ra) Miscellaneous observations upon authors ancient and modern, London. 
(I73Ib) Remarks upon the miscellaneous observations upon authors antient [sic] and modern: in several letters to a Friend, London.

(I790) Tracts, philological, critical, and miscellaneous, vol. 2, London.

Kapp, J. E. (1722) Clarissimorum virorum orationes selectae, Leipzig.

Kelley, D. R. (2002) 'Intellectual history and cultural history: the inside and the outside', History of the Human Sciences I5, I-I9.

Kenney, E. J. (I974) The classical text, Berkeley.

Klotz, C. A. (I764) Stratonis aliorumque veterum poetarum graecorum Epigrammata, Altenburg.

Konstan, D. and Muecke, F. (I992-93) 'Richard Bentley as a reader of Horace', Classical Journal 88.2, I79-86.

Lane Patey, D. (1997) 'The institution of criticism in the eighteenth century', in H. B. Nisbet and C. Rawson (I997) 3-3I.

Le Clerc, J. (1697) J. Clerici Ars critica, Amsterdam.

(I700) J. Clerici epistolae criticae et ecclesiaticae in quibus ostenditur usus artis criticae, Amsterdam.

(I709) Menandri et Philemonis reliquiae, Amsterdam.

(I710a) review of Burman (I709), Bibliothèque Choisie i9 (1709) 350-427.

(I7Iob) 'Raisons pourquoi on ne répond pas au libelle de Mr Pierre Burmann, Professeur à Utrecht', Bibliothèque Choisie 20 (1710) 450-56.

(I7I2) Joannis Clerici Ars critica, 4th edn, Amsterdam.

Levine, J. M. (I99I) The Battle of the books: history and literature in the Augustan age, Ithaca, NY.

(1994) 'Strife in the Republic of Letters', in Bots and Waquet (1994) 30I-I9.

Lillienthal, M. (1713) De Machiavellismo literario, sive de perversis quorundam in Republica Literario inclarescendi artibus dissertatio historico-moralis, Regensberg/Leipzig.

Loh-Kliesch, A (2012) 'Mencke, Johann Burckhardt', in Leipzig Lexicon: Lexikon/Enzyklopädie zur Geschichte und Gegenwart der Stadt Leipzig http://www.leipzig-lexikon.de/biogramm/Mencke_Johann_ Burckhardt.htm (last consulted May 2013).

Maber, R. G. (2005) Publishing in the Republic of Letters, Amsterdam.

McDayter, M. (2003) 'The Haunting of St. James's Library: Librarians, Literature, and "The Battle of the Books"', Huntington Library Quarterly 66, I-26.

Mehtonen, P. M. (2010) 'Transitional texts and emerging linguistic self-awareness', in R. Bod, J. Maat and T. Weststeijn (eds.) The making of the humanities: Volume I: early modern Europe, Amsterdam, 249-6o.

Mencke, J. B. (I715a) Compendiöses gelehrten-Lexicon, Leipzig.

(I7I5b) De Charlataneria eruditorum declamationes duae, Leipzig.

Momigliano, A. (1950) 'Ancient history and the antiquarian', Journal of the Warburg and Courtauld Institutes I3, 285-3I5.

Most, G. (I997) 'Classical scholarship and literary criticism', in H. B. Nisbet and C. Rawson, 742-57. Nisbet, H. B. and Rawson, C. (eds.) (I997) The Cambridge history of literary criticism, vol. 4, Cambridge.

Nisbet, R. G. M. (I986) 'A rival Teubner Horace', Classical Review 36, 227-34.

Ormiston, G. L. and Schrift, A. D. (eds.) (I990) The hermeneutic tradition: from Ast to Ricoeur, Albany.

Pansters, K. (2012) Franciscan values, Leiden.

Pitassi, M. C. (1987) Entre croire et savoir. Le problème de la méthode critique chez Jean Le Clerc, Leiden.

Renehan, R. (I988) 'Shackleton Bailey and the editing of Latin poetry', Classical Philology 83, 3II-28.

Richter, M. N. and Haltermann, C. D. (I696) Historia literaria delineata et illustrata, Rostock.

Romanus, C. F. (I698) Dissertatio academica de Republica litteraria, Leipzig.

Schoppe, K. (I762) De arte critica, Amsterdam.

Timpanaro, S. (2005) The genesis of Lachmann's method, ed. and trans. Glenn W. Most, Chicago.

Toland, J. (1726) A collection of several pieces of Mr John Toland, London.

van der Hoeven, A. (I843) De Joanne Clerico et Philippo a Limborch, Amsterdam.

van Lieshout, H. M. M. (I994) 'Dictionnaires et diffusion du savoir', in Bots and Waquet (1994) I3I-50. van Miert, D. (2010a) Humanism in an age of science: the Amsterdam Athenaeum in the Golden Age: 1632-1704, Leiden. 
van Miert, D. K. W. (2010b) 'Scaliger scatologus. Rhetorical roots of obscene and abusive language in the letters of Joseph Scaliger', EMF: Studies in Early Modern France I4, I7-3I.

van Rooden, P. (I994) 'Sects, heterodoxies, and the diffusion of knowledge in the Republic of Letters', in Bots and Waquet (I994) 5I-64.

Walpurger, J. G. (1715) Meditationes de genuina historia literaria, Wittemberg.

Walsh, M. (I99I) 'Bentley our contemporary: or, editor, ancient and modern', in I. Small and M. Walsh (eds.) The theory and practice of text-editing, Cambridge, $157-85$.

(1997) Shakespeare, Milton, and eighteenth-century literary editing: the beginnings of interpretative scholarship, Cambridge.

(ed.) (20I0) Jonathan Swift: a Tale of a Tub and other works, Cambridge.

Waquet, F. (ed.) (200o) Mapping the world of learning: the Polyhistor of Daniel Georg Morhof, Wiesbaden.

Witschi-Bernz, A. (I972a) 'Bibliography of works in the philosophy of history: I500-I80o', History and Theory I2, 3-50.

(I972b) 'Main trends in historical-method literature: sixteenth to eighteenth centuries', History and Theory I2, 5I-90. 